\title{
Correction to: Patients in intensive care unit for COVID-19 pneumonia: the lung ultrasound patterns at admission and discharge. An observational pilot study
}

B. Paolo Persona ${ }^{1 *} \mathbb{1}$, Ilaria Valeri ${ }^{2}$, Francesco Zarantonello ${ }^{1}$, Edoardo Forin ${ }^{2}$, Nicolò Sella ${ }^{2}$, Giulio Andreatta ${ }^{2}$, Christelle Correale², Eugenio Serra' ${ }^{1}$ Annalisa Boscolo ${ }^{1}$, Giovanni Volpicelli ${ }^{3}$ and Paolo Navalesi ${ }^{1,2}$

\section{Correction to: Ultrasound J (2021) 13:10}

https://doi.org/10.1186/s13089-021-0021-x

Following publication of the original article [1], we were notified that the first and last author names have been swapped.

The original article has been corrected.

\section{Author details}

${ }^{1}$ Institute of Anesthesia and Critical Care, Padua University Hospital, Via V. Gallucci, 13, 35121 Padova, Italy. ${ }^{2}$ Anesthesia and Critical Care, Department of Medicine-DIMED, University of Padua, Padua, Italy. ${ }^{3}$ Department of Emergency Medicine, San Luigi Gonzaga University Hospital, Torino, Italy.

Published online: 09 March 2021

\section{Reference}

1. Persona BP, Valeri I, Zarantonello F, Forin E, Sella N, Andreatta G, Correale C, Serra E, Boscolo A, Volpicelli G, Navalesi P (2021) Patients in intensive care unit for COVID-19 pneumonia: the lung ultrasound patterns at admission and discharge An observational pilot study. Ultrasound J 13:10. https://doi.org/10.1186/s13089-021-00213-x

\section{Publisher's Note}

Springer Nature remains neutral with regard to jurisdictional claims in published maps and institutional affiliations.

The original article can be found online at https://doi.org/10.1186/s1308 9-021-00213-x.

\footnotetext{
*Correspondence: ppersona75@gmail.com

1 Institute of Anesthesia and Critical Care, Padua University Hospital, Via V.

Gallucci, 13, 35121 Padova, Italy
}

Full list of author information is available at the end of the article

\section{Springer Open}

(c) The Author(s) 2021. This article is licensed under a Creative Commons Attribution 4.0 International License, which permits use, sharing, adaptation, distribution and reproduction in any medium or format, as long as you give appropriate credit to the original author(s) and the source, provide a link to the Creative Commons licence, and indicate if changes were made. The images or other third party material in this article are included in the article's Creative Commons licence, unless indicated otherwise in a credit line to the material. If material is not included in the article's Creative Commons licence and your intended use is not permitted by statutory regulation or exceeds the permitted use, you will need to obtain permission directly from the copyright holder. To view a copy of this licence, visit http://creativecommons.org/licenses/by/4.0/ 